\title{
Vulvar Cancer Pathologic TNM Finding v8
}

National Cancer Institute

\section{Source}

National Cancer Institute. Vulvar Cancer Pathologic TNM Finding v8. NCI Thesaurus.

Code C139595.

A pathologic finding about one or more characteristics of vulvar cancer, following the rules of the TNM AJCC v8 classification system. 